\title{
Exclusive Licensing in Harbour Towage
}

\author{
HENRY ERGAS, TERESA FELS AND JASON SOON*
}

Network Economics Consulting Group

\begin{abstract}
The question of whether exclusive licensing of the right to provide harbour towage services in ports can provide a superior outcome to open competition has been among the questions that have recently preoccupied Australian policymakers. The purpose of this paper is to evaluate the arguments for and against the introduction of exclusive licensing of harbour towage by way of a review of the more general literature on franchise bidding. The paper argues that the general policy trend in Australia towards greater acceptance of exclusive licensing arrangements for harbour towage in Australia is misguided because the costs of open entry tend to be overestimated while the practical difficulties of exclusive licensing tend to be underestimated.
\end{abstract}

\section{Introduction}

In March 2003 the Productivity Commission, the Australian Government's principal review and advisory body on microeconomic policy and regulation, publicly released its report entitled Economic Regulation of Harbour Towage and Related Services. ${ }^{1}$ The report was commissioned by the Government to enquire into the degree of competition in harbour towage and whether harbour towage prices should continue to be monitored. One of the issues examined in the report was the impact of exclusive licensing - the conferring of an exclusive right on a towage provider to serve a port for a specific period - on the competitiveness of harbour towage markets. The report recommended that the Government remove prices surveillance from all ports, and encourage port authorities to use exclusive licensing to license towage operators in their ports.

The purpose of this paper is to critically evaluate the arguments for and against the use of exclusive licensing presented to the Government by the Commission. The more general motivation of this critical evaluation is to provide a case study of the application of the economics of contract design to the problem of optimal harbour towage regulation.

The main lesson to be derived from this paper is that the incentive structure of the licensor (in this case, the port authority) is extremely relevant to the efficiency properties of the resulting license and this in turn determines whether exclusive licensing is more

* Henry Ergas, PO Box 5430, Kingston, ACT 2604, Australia, phone no.: 61-2-62326522. Email:

h.ergas@necg.com.au

${ }^{1}$ Productivity Commission (2002) Economic Regulation of Harbour Towage and Related Services, Report no. 24, Canberra. The Commission presented the report to the Federal Government in August 2002 but it was not publicly released until the following year. 
efficient than open competition. In the particular case of Australian harbour towage, we find that while on the "benefits" side, exclusive licensing may facilitate greater entry into the market by neutralising incumbency advantages, on the "costs" side we find the loss of incumbency advantages caused by exclusive licensing may be greater than is efficient, particularly when account is taken of a possible conflict of interest on the part of the port authority.

The end result, according to our analysis, is that encouraging port authorities to exercise their discretion to award exclusive licenses has the potential to reduce investment incentives in the harbour towage industry. Whether this resulting reduction in dynamic efficiency is worth the increase in competition for the market that may be promoted by exclusive licensing is an open question.

The paper is structured as follows. Section 2 discusses the harbour towage market in Australia and sets out the main features of the regulatory context. Section 3 provides a brief overview of the economic literature on exclusive licensing (also known as franchise bidding and competitive tendering), aiming to set out a conceptual framework for the subsequent discussion. Section 4 summarises the Productivity Commission's findings, while Section 5 evaluates the Productivity Commission's review of harbour towage in the light of the insights gleaned from the economic literature.

\section{The Australian harbour towage market}

\subsection{Harbour towage industry structure}

Towage is an essential intermediate service input for many of Australia's imports and exports, more than two-thirds of which (by value) are transported by sea. Tugboats are needed to assist ships arriving and departing from Australian ports because of the large size and limited manoeuvrability of ocean-going ships and restricted clearances in channels and berth areas.

The Australian harbour towage industry is relatively small, with Australia's total container throughput being less than one-fifth that of the Port of Singapore. Harbour towage services are provided at 51 Australian ports, with tugs permanently based at 45 ports. The largest ports receive over 2000 commercial ships each year while some of the smallest service fewer than 20. A number of ports in South Australia, where ship visits are relatively infrequent, have no resident tug boats, and receive towage services from Port Adelaide. Some ships, such as large tankers, require up to four tugs for safe berthing while others may require none.

Traditionally owned by a large number of family-run businesses, Australia's harbour towage industry consolidated significantly over the last two decades. By 1988 three companies (Howard Smith, Adelaide Steamship and Brambles) accounted for 80 per cent of the towage market ${ }^{2}$, with over half the harbour tugs in Australian ports controlled by joint ventures owned by these companies. By 1995 these companies provided towage services in 41 of the 51 ports, 23 by way of joint ventures. In 2001 Adsteam acquired Howard Smith's towage operations, making it the principal provider of harbour towage

\footnotetext{
${ }^{2}$ The three companies had interests in 80 per cent of the Australian fleet and assisted 81 per cent of ships requiring towage services.
} 
services in Australia. Currently, Adsteam operates 66 per cent of Australia's harbour tugs, mainly as a single operator. Table 1, reproduced from the Productivity Commission's report, lists the tug operators in all Australian ports as at March 2003. It shows that almost all ports are served by a sole tug operator.

\begin{tabular}{ll}
\hline Port & Towage provider \\
\hline New South Wales, all ports & Adsteam \\
Queensland, all ports & Adsteam \\
Except: & \\
Weipa & Adsteam (Comalco owns tugs) \\
Abbot Point & MIM and Adsteam jointly \\
Hay Point & BHP/Teekay Shipping \\
Dalrymple Bay & Dalrymple Marine Services \\
Victoria & \\
Melbourne & Adsteam and Australian Maritime Services \\
Hastings, Geelong & Adsteam \\
Portland & North West Shipping \& Towage \\
South Australia, all ports & Adsteam and Stannard/Adsteam \\
Western Australia & \\
Albany, Fremantle, Geraldton, Cockatoo Island & Adsteam \\
Bunbury & Riverwijs \\
Esperance & McKenzies Tug Service \\
Port Hedland & BHP/Teekay Shipping \\
Cape Cuvier & Hammersley Iron \\
Port Walcott & Robe River \\
Dampier/Hammersley & Hammersley Iron \\
Dampier/Woodside and public wharf & Riverwijs \\
Tasmania, all ports & North West Shipping \& Towage \\
Northern Territory & \\
Darwin & Stannard/Adsteam \\
Gove & Nabalco (Adsteam owns tugs) \\
Groote Eylandt & Gemco \\
\hline
\end{tabular}

\section{Table 1: Providers of habour towage}

The relationship between towage providers and the relevant port authority takes various forms. There is little vertical integration between port operators and towage providers, other than in some of the smaller ports. Open competition, in the sense of there being no exclusive license for the right to serve a port, continues to prevail in most Australian ports. Recently, however, some ports have commenced offering harbour towage licences to tug operators, either on an exclusive or non-exclusive basis. Exclusive licences prevent rival towage providers from entering the port, creating a monopoly for the incumbent towage provider for the duration of the contract. Non-exclusive licences permit multiple service providers to operate within the port, with no restriction on other providers competing for business. Table 2, reproduced from the Productivity Commission report, details towage arrangements by port as at March 2003. 
The bulk of the capital costs involved in providing towing services are accounted for by the purchase of tugs. However, labour and related expenses account for a large proportion of the costs of providing towage services. In the $1980 \mathrm{~s}$, a tugboat typically employed a crew of between five and eight people. This was reduced to a national standard of four in 1992. Recently, many tug crews have been reduced to three (a master, an engineer and a deckhand).

Revenue from Australian harbour towage operations was approximately $\$ 200$ million in 2001 - a little over 0.1 per cent of the value of goods shipped. Towage costs for containerised cargoes in 2001 accounted for between 10 and 20 per cent of port charges (excluding stevedoring) per container, but only about 2 per cent of total port and port interface costs.

\subsection{Regulation of harbour towage in Australia}

Regulation of the harbour towage industry at the Commonwealth level is principally through the general provisions of the Trade Practices Act 1974 (TPA), Australia's primary competition legislation. Australia's competition authority, the Australian Competition and Consumer Commission (ACCC), administers this legislation. The TPA's principal application to harbour towage is through provisions dealing with the unilateral misuse of substantial market power, and exclusive dealing which substantially lessens competition.

From 1991 to 2002, harbour towage services at the ports of Melbourne, Sydney (Port Botany and Port Jackson), Newcastle, Brisbane, Fremantle and Adelaide were declared services under the Prices Surveillance Act 1983 (PSA). Under the PSA, owners of declared goods or services are required to notify the ACCC of a proposed price increase. The ACCC then assesses whether the increases are justified.

There is also some environmental regulation at the Commonwealth level. The Australian Maritime Safety Authority (AMSA) was established under the Australian Maritime Safety Authority Act 1990 to enhance efficiency in the delivery of maritime safety and to prevent ship-sourced marine pollution. It charges fees to ships in Australian waters to fund the provision of maritime safety initiatives and facilities.

In addition, some States rely on Ministers and independent agencies for a degree of prices oversight over port charges. Victoria and South Australia have instituted price regulation of port services as part of their port reform process.

The final layer of regulation are towage guidelines for individual ports set by the individual port authority in consultation with other players in the market. Towage guidelines are justified on safety grounds. These guidelines usually prescribe the level of tugs required for a particular ship manoeuvre. Some ports' towage requirements are relatively prescriptive, varying according to vessel size, weather conditions and type of cargo. 


\begin{tabular}{|c|c|c|}
\hline Port & Port operator & Towage arrangement \\
\hline \multicolumn{3}{|l|}{ New South Wales } \\
\hline Newcastle & Newcastle Port Corporation & Open and charter \\
\hline Port Jackson & Sydney Ports Corporation & Open \\
\hline Port Botany & Sydney Ports Corporation & Open \\
\hline Port Kembla & Port Kembla Port Corporation & Open with service charter \\
\hline Eden & Port of Eden & Open \\
\hline \multicolumn{3}{|l|}{ Victoria } \\
\hline Melbourne & Melbourne Port Corporation & Open \\
\hline Geelong & Toll Ports & Service charter \\
\hline Portland & Port of Portland & Contract \\
\hline Hastings & Toll Ports & Service agreement \\
\hline \multicolumn{3}{|l|}{ Queensland } \\
\hline Weipa & Comalco & Contract \\
\hline Cairns & Cairns Port Authority & Non-exclusive licence \\
\hline Mourilyan & Mourilyan Bulk Sugar Terminal & Open \\
\hline Lucinda & Lucinda Bulk Sugar Terminal & Open \\
\hline Townsville & Townsville Port Authority & Exclusive licence \\
\hline Abbot Point & Abbot Point Bulk Coal & Port operator provides towage \\
\hline Mackay & Mackay Port Authority & Non-exclusive licence \\
\hline Hay Point & Hay Point Services (BHP) & Port operator provides towage \\
\hline Dalrymple Bay & Dalrymple Bay Coal Terminal & Contract \\
\hline Gladstone & Gladstone Port Authority & Exclusive licence \\
\hline Bundaberg & Bundaberg Port Authority & Exclusive licence \\
\hline Brisbane & Brisbane Port Corporation & Open \\
\hline \multicolumn{3}{|l|}{ Western Australia } \\
\hline Esperance & Esperance Port Authority & Non-exclusive licence \\
\hline Albany & Albany Port Authority & Exclusive licence \\
\hline Bunbury & Bunbury Port Authority & Exclusive licence \\
\hline Kwinana & Fremantle Port Authority & Non-exclusive licence \\
\hline Geraldton & Geraldton Port Authority & Exclusive licence \\
\hline Fremantle & Fremantle Port Authority & Non-exclusive licences \\
\hline Cape Cuvier & Dampier Salt & Towage provided by port operator \\
\hline Port Walcott & Robe River Iron Associates & Towage provided by port operator \\
\hline Dampier & Dampier Port Authority & Port users provide towage \\
\hline Port Hedland & Port Hedland Port Authority & Informal arrangement with BHP \\
\hline Cockatoo Island & Portman & Contract with mine operator \\
\hline \multicolumn{3}{|l|}{ South Australia } \\
\hline Port Giles & Flinders Ports & Open \\
\hline Adelaide & Flinders Ports & Open \\
\hline Port Pirie & Flinders Ports & Open \\
\hline Ardrossan & Ausbulk & Open \\
\hline Wallaroo & Flinders Ports & Open \\
\hline Port Lincoln & Flinders Ports & Open \\
\hline Whyalla & $\mathrm{BHP}$ & Open \\
\hline Port Bonython & Santos & Open \\
\hline Thevenard & Flinders Ports & Open \\
\hline Port Stanvac & Mobil & Open \\
\hline
\end{tabular}




\begin{tabular}{|c|c|c|}
\hline \multicolumn{3}{|l|}{ Tasmania } \\
\hline Hobart & Hobart Ports Corporation & Open \\
\hline Burnie & Burnie Port Corporation & Open \\
\hline Devonport & Port of Devonport Corporation & Open \\
\hline Port Latta & Hobart Ports Corporation & Open \\
\hline Launceston & Port of Launceston & Open \\
\hline \multicolumn{3}{|l|}{ Northern Territory } \\
\hline Darwin & Darwin Port Corporation & Open \\
\hline Gove & Nabalco & Towage provided by port operator \\
\hline Groote Eylandt & GEMCO & Towage provided by port operator \\
\hline
\end{tabular}

Table 2: Towage arrangements by ports

\subsection{How the harbour towage industry is organised in other countries}

In this section we briefly review how the harbour towage industry in other countries is organised $^{3}$. As will be evident, the review suggests that there is a diversity to the organisation of harbour towage in other countries. This diversity means that conclusions about the existence of natural monopoly in one country and therefore conclusions about the desirability of different policy options in one country are not necessarily easily extrapolated to other countries.

\subsubsection{European Union}

There is no price regulation of harbour towage at either the EU or member-state level. However, general competition rules and competition laws at the member state level apply to port services, including harbour towage.

Industry-specific regulation of the ports industry, including harbour towage (for example standards for training and qualifications of crews), is undertaken at the memberstate level and is considerably diverse. There is a range of entry restrictions into the towage industry in European ports, from no restrictions on entry and no limits to the number of firms that may operate (ports of Rotterdam and Tilbury), to complete restriction. Competitive tendering for harbour towage services is commonplace in French ports.

\subsubsection{US}

In US ports, multiple privately-owned towage companies compete to provide towage services in publicly-owned landlord ports. There is no price regulation or disclosure regime applying to harbour towage in the US though there is regulation at the federal level that restricts entry by foreign providers. The main regulators of harbour towage in the US are the US Coast Guard and the Federal Maritine Corporation (FMC). The Coast Guard certifies all commercial vessels, including tugboats, to meet minimum safety and environmental requirements. The FMC is responsible for economic regulation of towage operators under the Shipping Act 1984 by investigating cases of anti-competitive practices in the maritime industry.

\subsubsection{Canada}

As in the US, private companies provide harbour towage services in landlord ports. However, all ports in Canada except the Port of Vancouver have only a single provider of

\footnotetext{
${ }^{3}$ Information for this section is sourced from Charles River Associates (2001).
} 
harbour towage. It is believed that the reason for this is that that port traffic in other Canadian ports is too low to support more than one operator.

Transport Canada is responsible for regulating commercial vessels for safety and environmental standards. The Canadian Transportation Agency, under the Canada Transportation Act 1996, is responsible for economic regulation of towage and other maritime industries. General competition laws under the Competition Act 1986 apply to harbour towage in Canada. Towage rates in Canada are determined by negotiation between towage providers and shipping lines.

\subsubsection{New Zealand}

In New Zealand, the small number of towage jobs essentially means that harbour towage is provided by one operator in each port. While there are no explicit regulatory barriers to entry into the provision of towage services, in most cases towage is provided by the port operator.

Towage operators must comply with relevant Maritime Safety Authority regulation and other towage guidelines set by the port or government. But there is no form of price control. Harbour towage services are subject to general competition law under the Commerce Act 1986, administered by the Commerce Commission. This Act prohibits companies taking advantage of market power for certain anti-competitive purposes and prohibits contracts or arrangements which substantially lessen competition.

\subsubsection{Singapore}

Prior to the privatisation of the Maritime and Port Authority (MPA) of Singapore in 1997, the public port authority was the sole provider of harbour towage. New entrants into the towage industry were prohibited and regulation was prescriptive. In 1997, the MPA began phasing in competition in towage services by issuing 30-year licences to new operators. The MPA now licenses competing private providers of harbour towage services. Licensing covers minimum training and safety standards and assesses the company's operational capabilities. Licences are issued periodically at the discretion of the MPA.

Towage charges are determined by negotiation between towage providers and shipping lines but towage pricing is controlled by a published tariff that defines the maximum that can be charged based on ship size per tug.

\subsubsection{Malaysia}

Port Klang comprises two main competing port terminals, each operated by a publiclylisted port company. Each port company operates its terminal as a service port, providing harbour towage without competition from independent providers. The Malaysian Government imposes a system of price control on harbour towage services in the form of a maximum tariff. Harbour towage is also governed by industry-specific regulations relating to safety and training.

\section{The case for and against franchise bidding}

The concept of franchise bidding may have originated with the Victorian social reformer, Edwin Chadwick. In an article published in 1859, Chadwick introduced the distinction between competition "within the field" and "competition for the field". He argued that in situations where market competition failed to work, such as in the case of natural 
monopolies, ${ }^{4}$ centrally administered competitions "for the field" could act as an effective substitute for competition in a market. ${ }^{5}$ Rival firms bidding to secure the market would set prices at cost, while regulation could be used to ensure the provision of adequate service quality.

Chadwick's views were largely forgotten until the publication of an influential article by Demsetz in $1968 .{ }^{6}$ Demsetz argued that franchise bidding had the potential to introduce competition into areas of natural monopoly. A central authority would auction the rights to the natural monopoly. Potential suppliers would bid by quoting prices at which they were prepared to supply the market. The supplier quoting the lowest price would be offered the franchise. Competing bidders would drive the price down to a competitive levels and no monopoly rents would be made.

An important implication of Demsetz's work was that franchise bidding rendered direct regulation of natural monopolies, for example through rate of return regulation, unnecessary. The article stated that "the rivalry of the open market place disciplines more effectively than do the regulatory processes of the commission." Demsetz's work was influenced by the widely held view of the period that US public utility regulation had largely failed in its objectives. ${ }^{7}$

Other leading commentators who supported the idea of franchise bidding for the right to serve a market were Stigler ${ }^{8}$ and Posner. Stigler illustrated the application of the idea to electricity distribution and generation, and Posner advocated franchise bidding in the context of regulation of the cable television industry. ${ }^{9}$

One limitation of these papers is that they failed to fully explore the practical implications of implementing franchise bidding..$^{10}$ These issues were taken up in the 1970s by Williamson ${ }^{11}$ and Goldberg ${ }^{12}$ who argued that for franchising to be successful a great deal rides on contract design and monitoring agencies.

\footnotetext{
${ }^{4}$ A natural monopoly industry is one where average costs are minimised at existing demand levels by a single producer producing the entire market's output.

${ }^{5}$ E. Chadwick (1859) "Results of Different Principles of Legislation in Europe: Of Competition for the Field as Compared with Competition within the Field of Service," Journal of the Royal Statistical Society, 22: 381.

${ }^{6}$ H. Demsetz, (1968) “Why Regulate Utilities?” Journal of Law \& Economics, 11.

${ }^{7}$ See the literature review by Littlechild, S. (2002) "Competitive bidding for a long-term electricity distribution contract", Review of Network Economics, 1.

8 "Natural monopolies are often regulated by the state. We note that customers can auction off the rights to sell electricity, using the state as the instrument to conduct the auction .... The auction now consists of a promise to sell cheaply," p. 19 of Stigler G J (1968) The Organisation of Industry, University of Chicago Press, Chicago.

${ }^{9}$ Posner proposed a statute that reads in part “(1) ... Municipal authorities would be permitted - and encouraged - to auction off franchises to the firm promising to provide cable service at the lowest rates to subscribers... (2) States would be permitted, but not required, to regulate cable television companies as common carriers or public utilities. Realism would appear to dictate such a provision, whatever its wisdom, and any bad effects would be mitigated by provision (5) (a) below. ... (4) The FCC would be forbidden to regulate cable television, with three exceptions... (5) An Office of Cable Communications would be established in the federal government. It would have several functions (none regulatory): (a) To evaluate state and local regulation of cable television, to advise [on this] and to submit to Congress proposals for modifying state or local regulatory authority where such a course seemed indicated." pp. 126-7 of Posner, R A (1972) "The Appropriate Scope of Regulation in the Cable Television Industry," The Bell Journal of Economics and Management Science, 3: 98-129.

${ }^{10}$ Some exploration of the problems appears in Demsetz, H. (1971) "On the Regulation of Industry: A

Reply," Journal of Political Economy, 79: 357.

${ }^{11}$ Williamson, O E (1976) "Franchise Bidding for Natural Monopolies - in General and with Respect to CATV," The Bell Journal of Economics, 7: 73-104.
} 
First, Williamson and Goldberg recognised that franchise bidding contracts, like other contracts, can suffer from contractual incompleteness. Incompleteness arises because of the difficulty in foreseeing all possible future contingencies and also because changes in conditions require that contracts have adjustment rules. Incompleteness can create important gaps in the relationship between the licensing agency and the franchisee, which can create opportunities for ex post opportunistic behaviour on the part of either party.

The second set of problems arises from the difficulty of monitoring and enforcing contract performance. Monitoring problems arise because of information asymmetries between the franchisee and franchisor. Enforcement difficulties are caused because third parties (such as courts) have difficulty verifying performance with certain contract variables, in particular those relating to quality. In a competitive market these problems would be corrected by market forces. The exclusive licence, however, creates an entry barrier that does not permit this to occur. ${ }^{13}$

Third, if an incumbent operator gained advantages from incumbency in seeking contract renewal, then the strong competition that might have surrounded the initial grant would progressively weaken. As it did, the outcome under franchise bidding would approach that yielded by an unregulated monopoly. ${ }^{14}$

All these problems were associated with outcomes that fell short of the competitive ideal. Williamson and Goldberg concluded that there were problems with both franchise bidding and rate of return regulation.

More recently, economic literature has focussed on the disincentives for investment that may be promoted by franchise bidding. ${ }^{15}$ This problem arises when the winning firm is required to make sunk-cost investments the life of which exceeds the time period of the franchise contract. The difficulty of placing a residual value on sunk transaction-specific assets, and the possibility of opportunistic behaviour on the part of the franchisor, can create disincentives for a franchisee to invest efficient amounts into the asset in question. This occurs because the franchisee foresees that possible undervaluation of the asset creates a considerable risk that it will not recover its investment, much less appropriate the full social gain it creates.

The Williamson and Goldberg critique of franchise bidding seems to have prevailed in the economics literature. For instance, Schmalensee argues that franchise bidding would work with simple contracts, as those involved in taxi licence plates. However, where the industry is a natural monopoly, the difficulties of contract specification and administration

\footnotetext{
${ }^{12}$ Goldberg, V P (1976) "Regulation and Administered Contracts," The Bell Journal of Economics, 7: 42648.

${ }^{13}$ For example, where a right to operate an essential facility - that is, a facility which provides services essential to competition in a dependent market - is being auctioned, the winning firm may be able to claim monopoly rents in that dependent market. Such a firm may benefit from discriminating between firms in that dependent market in terms of the quality of service it provides. It may provide preferential treatment to one firm, and share in the rents from the resulting distortion of downstream competition. Preventing such rentsharing arrangements requires effective monitoring of the comparative service quality provided to a range of entities - which may be difficult.

${ }^{14}$ See generally Williamson, O. (1985) The Economic Institutions of Capitalism, Free Press, New York.

15 Though this problem too has been known for some time: see the extensive discussion in Schmalensee, R. (1979) The Control of Natural Monopolies, D.C. Heath \& Co., Lexington.
} 
would be substantial. ${ }^{16}$ Similarly, Armstrong, Cowan and Vickers argue that franchise bidding works best for markets where there are low sunk costs. ${ }^{17}$

\section{Summary of the Productivity Commission's findings on use of exclusive licensing in harbour towage}

The Commission considered that the provision of harbour towage services exhibits natural monopoly characteristics at the level of individual Australian ports and concluded that there was little scope for sustainable long-term competition within most, if not all, Australian ports. It considered that even where it is possible for a new entrant to challenge an incumbent towage operator (as was likely to be the case in the larger ports), only one provider would survive in the long run. The Commission considered that a natural monopoly existed because of indivisible investment and economies of scale and scope. Its key findings in these respects are set out below.

\subsection{Indivisible investment}

The Commission found that the Australian harbour towage industry was characterised by indivisible investment. Indivisible (or "lumpy") investment means that investment can be undertaken economically only in increments that are large relative to the size of the market.

The Commission's finding appears at first glance to be at odds with the fact that the minimum investment required to be a tug operator is not a single tug but the group of tugs required to service a particular port. Nonetheless, investment can be indivisible because some port authorities impose minimum towage requirements on towage operators. The purpose of these requirements is to avoid shipping channels being blocked or port facilities being damaged due to insufficient tugs being used. The ultimate effect of these requirements is that in some ports only one provider is feasible in the long term.

\subsection{Economies of scale}

The Commission found that significant spare capacity at most ports means that there is scope for increases in tug jobs to be handled at lower cost by a single operator rather than by new entry. In support of this proposition, the Commission referred to the entry of BHP Transport in conjunction with four Japanese shipping operators (HTS) into towage at Newcastle in the 1990s. This attempted entry lasted less than five years, during which time both HTS and the incumbent appear to have made losses, before Adsteam purchased HTS in 1999.

\subsection{Economies of scope}

According to the Commission:

At the individual port level, the main economies of scope in harbour towage are the simultaneous provision of salvage and fire-fighting services. At ports where such important services are required, only one provider is likely to be needed given the limited requirements for them

\footnotetext{
${ }^{16}$ Schmalensee, R (1979) The Control of Natural Monopolies, D C Heath \& Co, Lexington, Mass.

${ }^{17}$ Armstrong, M, S. Cowan and J. Vickers (1994) Regulatory Reform: Economic Analysis and British

Experience, The MIT Press: Cambridge, Mass., and London, England.
} 
The Commission does not elaborate on this point but given that it is not decisive to proving the case of natural monopoly and that for the sake of argument, we accept the Commission's finding that a natural monopoly exists, this issue will not be discussed any further.

\subsection{No sunk costs}

The Commission found that although harbour towage was reasonably capital intensive, it did not involve large sunk costs. The existence of a well-established market for secondhand tugs prevented investments in tugs being largely unrecoverable on exit. The Commission qualified this view by noting that the second-hand market for tugs was located offshore and hence transport costs to the point of sale would be incurred. Further, it noted that the value of any special modifications required for Australian ports was likely to be lost on resale.

\subsection{Natural monopoly at groups of ports?}

The Commission was somewhat inconclusive about whether natural monopoly existed beyond the individual port level to a group of ports. It was unclear that there were significant cost advantages in one firm providing towage across all of the geographicallydispersed ports.

The Commission concluded that:

Most if not all Australian ports can efficiently support only one towage service provider in the longer term. There are cost advantages for a single common operator across some regional groupings of ports. However, natural monopoly characteristics do not extend to one operator providing towage at all ports in Australia or even at all of the major container ports.

\subsection{Natural monopoly may be contestable}

Significantly, the Commission's recognised that even if harbour towage is a natural monopoly, the natural monopoly may be contestable. Contestability refers to a situation in which the sunk costs involved in entry are so low, relative to the time it takes an incumbent to respond to entry, that entry will occur whenever the incumbent's revenues prior to entry exceed total costs. A contestable natural monopoly may replicate the outcomes of a workably competitive market.

Whether a market is contestable depends on whether there are barriers to entry and exit. Entry and exit barriers are simply factors that allow an incumbent firm to earn monopoly profits - their essence is that they involve an asymmetry between the incumbent and potential entrants.

In the case of the harbour towage market, there appear to be relatively minor entry barriers. As noted above, the Commission concluded that only minor sunk costs exist in the harbour towage market. It also recognised that regulatory requirements, in particular prescribing the minimum number of tugs required for certain types of ships or weather conditions, create relatively minor barriers to entry. It found that:

Barriers to entry into the towage market include the costs of transporting tugs, losses on resale of tugs, development of a customer base, training of crews and redundancy payments on exit. Available evidence suggests that these barriers, while not insignificant, are not large. There is a pool of alternative towage operators able to enter the Australian market. 


\subsection{Three forms of competition "for" the market}

The report canvassed three possible forms of competition for the right to service the entire market, each of which would generate competitive pressures:

- A new entrant could commence operations and compete vigorously with the incumbent until one firm was forced to exit the market;

- A process of mergers or takeovers could lead to a single towage provider in a particular port; or

- The government, port authority or users could conduct a tender for the right to provide towage services in the port for a specified period of time (for example the exclusive licence model).

The first two options can both be characterised as means of non-exclusive licensing for the right to serve a port in the context of what is otherwise open competition. The costs associated with the two options are discussed together below.

\subsection{Costs of "open competition"}

\subsubsection{Costs from the "war of attrition"}

The Commission argued that open competition where only one operator was ultimately viable would be undesirable, as it would be associated with a "war of attribution" with three principal social costs.

First, open competition could generate significant uncertainty among industry participants. This uncertainty could dissuade players from making long-term investments and discourage users from entering into long-term contracts with a particular towage provider.

Second, a war of attrition could produce long term inefficient pricing. Prices would range from a level which was loss-making for operators during the competitive period, while being above average cost (reflecting the extent of barriers to entry) when only one operator remained.

Finally, the Commission argued that resource costs are incurred when two or more operators are competing to win a market. This would result in excessive expenditure in capital equipment (in the form of tugs and land-side facilities) and in labour.

\subsubsection{Mergers and takeovers}

A merger or takeover is one way of ending a "war of attrition" between two towage providers. Thus, open competition may result in industry rationalisation. However, the Commission considered that mergers and takeovers are not a costless mechanism for resolving a war of attrition. In addition to the resource costs incurred wastefully before the "war" is resolved, there are costs involved in preparing the takeover documents and in implementing the consolidation.

\subsection{Benefits of an exclusive licensing contract in harbour towage}

The Commission concluded that: ${ }^{18}$

${ }^{18}$ Chapter 8 of Productivity Commission (2002) Economic Regulation of Harbour Towage and Related Services, Report no. 24, Canberra. 
Competitive tendering for the right to provide towage services in a port offers an alternative and potentially more effective mechanism for promoting competition "for" the towage market in a port, resulting in more efficient pricing and service outcomes.

The Commission considered that the use of exclusive licensing in contracting for harbour towage service could capture the benefits discussed below.

\subsubsection{Increase in competitive pressures}

The Commission essentially accepted that the grant of an exclusive licence was a form of "competition for the market" superior to "competition in the market". It considered that the introduction of exclusive licensing would result in a reduction in the prices charged by tug operators. In particular, the Commission accepted the argument made by some industry players that exclusive licensing, by guaranteeing market share outcomes, could encourage entry into the market by overcoming incumbency advantages.

The Commission noted some instances where exclusive licensing supported by competitive tendering had led to a fall in prices. It viewed these price falls as evidence that "competition for the market" could work as a discipline on pricing and output decisions.

\subsubsection{Reduced transition costs and costs from war of attrition}

The Commission argued that under a tendering process, a "managed" transition to a new towage operator in a port can be organised, thus avoiding the costs of a "war of attrition"

\subsubsection{Other benefits}

The Commission discussed other benefits in relation to the practice of tendering - the most important of which were: the savings in transaction costs arising from having the port authority contract on behalf of users; being able to specify explicit quality controls in a tendering contract; and greater certainty of operations and prices. However, these benefits also apply to contracting under a non-exclusive licence, as is discussed in greater detail below.

\section{Critical assessment of the Productivity Commission's report}

This section critically assesses the Commission's view that harbour towage services should be provided by means of an exclusive licence.

\subsection{Contestable natural monopoly}

The Commission's view that the introduction of exclusive licensing would result in a reduction in the prices charged by tug operators appears to be inconsistent with its recognition that the existence of natural monopoly does not automatically imply absence of competitive pressure. As noted above, a contestable natural monopoly may replicate the outcomes of a workably competitive market. The fact that there has been little observed entry in many ports before introduction of an exclusive licensing regime is equally consistent with there being a contestable market. If an incumbent had been constrained by contestability, no entry would have been observed. If this were the case it seems unlikely that exclusive licensing would indeed result in sustainable price reductions.

However, this does not mean that price falls cannot be secured. Rather, to the extent

price reductions are observed post-tender, these may reflect the expropriation by means of the tender of previously incurred sunk costs - a point discussed further below. 
Additionally, in an efficient market, prices will reflect marginal costs. However, in a competitive uniform price auction, the winning bid will be set to average cost. If marginal costs exceed average costs at competitive output, the auction will result in an apparent fall in prices. That price reduction will be inefficient, as it will result in the expansion of output beyond the socially optimal point.

As a result, it is dangerous to rely on price falls alone as evidence of the success of "competition for the market".

\subsection{Non-exclusive licensing may be preferable}

In arguing that a more systematic contracting process is superior to open competition, the Commission did not appear to differentiate between non-exclusive licensing and exclusive licensing. This is an important omission because non-exclusive licensing can address some of the costs associated with "war of attrition" referred to above. If open competition is best avoided, it is possible to have a more structured process for switching between competing firms through a non-exclusive contract which does not introduce the additional degree of restrictiveness of making the licence exclusive.

An example of non-exclusive tendering is the relationship between Bunbury Port Authority (BPA) and Adsteam prior to the introduction of exclusive licensing at the Port Bunbury. This was the subject of the Full Federal Court's decision in Stirling Harbour Services Pty Ltd v Bunbury Port Authority. ${ }^{19}$ In July 1986, the BPA entered an agreement with a subsidiary of Adsteam for the provision of tugboat services at the Port of Bunbury for a term of fourteen years. The agreement could be terminated by either party by giving two years' notice. The agreement set out the rates that could be charged for services. However, rates could by reviewed regularly and, if BPA agreed, varied over time so as to ensure Adsteam was reimbursed for all operating costs. Any disagreement on rates would be resolved by arbitration.

In the case of the Port of Bunbury there would have been little need for a costly war of attrition. Given that the contract was reviewable at regular intervals, it would have been possible for a new entrant to prepare in advance a detailed business plan and approach the Port Authority with a better contract. The resulting making and breaking of contracts could be organised to reduce the uncertainties discussed by the Commission.

\subsection{Port authority conflict of interest and its implications}

There is something peculiar about the logic of the Commission's recommendations. On the one hand it claims that entry into the harbour towage market may be hampered due to over-restrictive requirements on towage operators placed by port authorities: ${ }^{20}$

...[A]n indirect regulatory barrier to promoting competition within the towage market may be the specification by port authorities of the number of tugs required ... If guidelines are overly cautious and pilots lack discretion over the number of tugs required, this may force a new entrant to enter the market with more tugs than are required to service the market (and meet safety requirements). The higher start-up capital costs may deter entry and forestall competition in the market, thereby limiting scope for competition "within" the market.

On the other hand it argues that the solution to this problem is to cede greater power and discretion to port authorities to restrict entry into the harbour towage market. The

\footnotetext{
${ }^{19}$ [2000] FCA 38 (28 January 2000).

${ }^{20}$ Chapter 8 of Productivity Commission (2002) Economic Regulation of Harbour Towage and Related Services, Report no. 24, Canberra.
} 
transaction costs of users dealing directly with towage providers are likely to justify port authorities making towage contracts on users' behalf. However, there are obvious risks involved in a policy of exclusive licensing which may serve to entrench the mistakes of port authorities for a long period of time.

The Commission appeared unaware of the systemic incentives port authorities may have to set towage rates at inefficiently low levels. Why might such incentives exist?

One reason is that port authorities have an incentive, and indeed a commercial obligation, to engage in behaviour which improves their own financial returns. At the same time, however, port authorities are effectively price regulated, either formally or by means of a system of informal oversight. They are, therefore, restricted from increasing the prices that they themselves charge end-users (for example the shipping operators).

The exclusive licensing process enables port authorities to obtain cost reductions from towage operators, thereby increasing their own profits. By so doing the port authority maintains the good graces of its shareholders and other stakeholders, albeit at the cost of distorting incentives for investment. ${ }^{21}$ How might this be achieved?

The port authority provides services to shipping operators that complement those provided by towage providers. In deciding whether to dock at a particular port, shipping operators consider the aggregate price ("end price") of all port and port-related services rather than the individual prices charged by each service provider. By forcing down the prices of complementary services the port authority can engage in cost shifting. This can be concealed from external regulators and shipping operators, who do not observe any increase in end prices (and may even observe decreased prices). The port authority can achieve this effect by coercing towage operators to pass on what would have otherwise have been gains on sunk investments arising from temporary increases in price-cost margins. Such gains are most commonly the result of investments that result in cost reductions or product improvements.

The port authority can then engage in the following conduct:

- $\quad$ holding fixed the price to end-users and increasing its own profits;

- $\quad$ reducing end prices to end-users while not reducing its own prices;

- holding end prices fixed or reducing these while pursuing a "quiet life" and so avoiding undertaking what would otherwise be efficient cost reductions in its own operations ; or

- $\quad$ some combination of all the above.

Thus, the port authority has the ability to reduce the prices to end-users of other complementary services even if this results in prices below efficient levels for those services. While it is obviously difficult for the port authority to force prices of

\footnotetext{
${ }^{21}$ The PC itself expresses some reservations about the ability of port authorities to act in the best interests of port users:

"Though there is a sizeable pool of potential towage providers, as evidenced by the number of bidders for the Bunbury and Fremantle exclusive licences, the ability of, and incentive for, government-owned port authorities to act in the interests of users are less clear."(p. xxxii)

An additional problem with non-privatised ports is that they face conflicting and unclear objectives. As a result, port users' interests are even far less likely to receive proper weight.
} 
complementary services below cash costs, the nature of sunk costs means that it is easier to force prices to levels that do not permit the recovery of sunk costs.

Harbour towage providers, like any other firms, undertake investments if those investments are expected to earn their cost of capital. However, the argument for allowing towage providers to recover the costs of their investment does not require the granting of any enduring or substantial market power. Rather the point is that the potential for shortterm, Schumpeterian, profits create incentives for firms to make investments that result in cost reductions or product improvements. Until rivals catch up, the innovator earns short run rents. It is exactly the prospect of these "rents" that spurs innovation. Similarly, sunk costs are made recoverable by frictions in the market that prevent every dollar of profit being instantly competed away. It is precisely these frictions which ensure that workably competitive markets - unlike markets that are perfectly competitive - can induce and reward investment in innovation, and hence are generally desirable.

A simple example illustrates this point. The marginal cost of providing a service is $\$ 5$, which is also the price charged to the consumer of the service. By engaging in a costly investment, a firm that provides the service can reduce the marginal cost to $\$ 3$. It considers that the new profit-maximising price is $\$ 4$ for as long as it takes its competitors to catch up. Its short run return from the $\$ 4$ price will allow it to recover all investment costs. At this price, it keeps $\$ 1$ of the cost reduction while the consumer enjoys the remaining $\$ 1$ of the cost reduction. Ex post consumers would benefit if the price fell to $\$ 3$, but if the firm saw no prospect of being able to claim the $\$ 1$ it would not have engaged in the innovation in the first place. The price and marginal cost would subsequently have remained the same and no one would have been better off.

This example demonstrates that it is socially desirable for a firm that invests in innovation to enjoy innovation rents to the extent necessary to motivate its original investment. It would be socially undesirable if these innovation rents were expropriated by another party, whether that be the final consumer, a port authority or another competitor.

The social gain from securing a productivity improvement will usually outweigh the cost associated with any allocative inefficiency due to its pricing. The increase in social surplus that arises from shifting down the entire cost curve may end up being large relative to losses caused by temporary supracompetitive pricing.

The expropriation scenario described above can also occur under franchise bidding, if, towards the close of the franchise period, the value of assets held by the incumbent cannot be perfectly observed. If there is an unresolved dispute over the value of the assets, then the following may occur:

- if the incumbent wins the next tender, the new franchise contract may sets prices insufficiently high for the incumbent to recover the investment made in the previous period; or

- if the incumbent loses the next tender, it may be required to sell its assets to the winning bidder at a price which does not allow for cost recovery.

Opportunistic conduct on the part of the port authority signals to port operators that outlays made in improving or expanding the market are capable of being expropriated, thereby discouraging investments in further innovation in towage. While such behaviour on the part of the port authority appears short-sighted, it may be rational in the context of a port authority that may not bear the long-term consequences of reductions in investment 
induced by its conduct. ${ }^{22}$ This highlights a possible danger of exclusive licensing - namely, the possibility that the franchisor's conduct could discourage investments that would ultimately have benefited consumers. The risk that port authorities will use their regulatory powers to secure gains for themselves, but with adverse consequences for efficiency going forward, is not given careful attention in the Productivity Commission's report.

It is worth briefly discussing a recent paper by Gans and King ${ }^{23}$ which appears to reach opposite conclusions from those presented in this section. Gans and King model the bargaining between a port authority and a towage provider as bargaining between complementary input providers. Their modelling finds that if the towage operator and port authority bargain over service quality and then unilaterally set prices (as they might do absent competitive tendering for an exclusive licence) then a wide variety of outcomes are possible. These would include quality/service levels below those of an integrated port/towage company and below service levels that would maximise joint profits.

The intuition behind this result is that each party wishes to extract as much as possible from the other. The final outcome depends on the relative degree of market power enjoyed by each party. The parties undermine each other's profits because there is a negative pricing externality - as towage services are complementary to port services, the higher the prices of the former, the lower the demand for the latter and vice versa.

The paper then models the results where the port authority is allowed to tender for both price and quality of towage services ${ }^{24}$. It finds that if "side payments" between the two are not allowed and one side has more market power than the other then there will tend to be an underprovision of service quality for the less market power-endowed input. ${ }^{25}$ The intuition here is that the party with more market power will have an incentive to raise prices even though this reduces demand. Knowing that demand will be reduced, the party with less market power will invest less in the other input, leading to suboptimal quality because of the underinvestment.

Gans and King find that these problems can be resolved if side payments between towage providers and port authorities are allowed. Side payments can be used to internalise the external pricing effects that led to inferior outcomes under the previous scenarios. The side payments achieve the same effects as the merger of port authorities and towage providers.

While the results derived by Gans and King are of interest, it is doubtful that the policy implications of the Gans and King model are practicable. First, the actual tenders used in

\footnotetext{
${ }^{22}$ The dangers of such "hold-up" on the fruits of investment are well known. The problem of hold-up occurs when one party supplies an asset to another party which has attributes which means it can only be used by the latter. Once the asset is built, the using party can hold-up the supplying party, forcing poor contractual terms on it, since the supplying party can only either accept the terms or abandon its investment. Indeed, hold-up costs are such a significant potential problem that they may explain various patterns of industrial organisation in the economy. See for instance Ramseyer, J.M. and Y. Miwa (2000), "Rethinking Relationship-Specific Investments: Subcontracting in the Japanese Automobile Industry", Harvard Law and Economics Discussion Paper No. 282; Klein, B. (1996) "Why Hold-Ups Occur: The Self-Enforcing Range of Contractual Relationships," Economic Inquiry 34: 444-63.

${ }^{23}$ Gans, J. and S. King (2003) "Contestability, complementary inputs and contracting: The case of harbour towage," Australian Economic Review 36: 415-27.

${ }^{24}$ It also models the results of direct customer contracting with towage providers but this is irrelevant to our discussion as we have already accepted the limit that any contracting plausibly will be by port authority as representative of towage users. In any case, the results are similar assuming zero transaction costs and it is only if transaction costs were zero that the possibility of direct customer contracting can be relevant.

${ }^{25}$ The same occurs if one party operates in a less contestable than the other.
} 
the industry do not permit side payments. To do so would require the widest possible discretion in tender bids between port authorities and towage providers. However, this could create other problems such as possible corruption and lack of transparency in bidding. Second, their model does not consider the dynamic efficiency notions discussed in this paper arising from hold-up of past investments in innovations.

\subsection{Other costs of exclusive licensing}

The general discussion of exclusive licensing in the previous section provides a conceptual framework for categorising the various types of costs associated with exclusive licensing. Some of these are of particular relevance to the provision of harbour towage services.

\subsubsection{Contractual design and enforcement}

Two of the three principal problems with exclusive licensing identified by Williamson are essentially problems relating to contract design. Specifically, problems can arise when:

- the initial award criteria were inadequately specified; or

- $\quad$ execution problems develop in the price-cost relationship, for instance, how to hold parties to agreed terms and conditions given difficulties of measurement and other uncertainties.

While these problems can also arise under non-exclusive licensing, there is a greater difficulty in resolving these under exclusive licensing, because of the difficulty of terminating such contracts and switching suppliers.

The difficulty of specifying precise "award criteria" arises where awarding the contract depends on non-price as well as price-based criteria. Problems can arise because quality variables are typically difficult to capture or measure, and yet end-users may have different preferences over these variables. ${ }^{26}$ Quality as well as price is important in harbour towage, amongst other reasons, because of the need for reliability and salvage capability. ${ }^{27}$ Further specification difficulties arise where price itself is not a single parameter but can vary over different parameters (for example, volume rebates). As a result, the bidding process necessarily is multidimensional in price/quality combinations. Another aspect of the award criterion problem is that it may foreclose the ability of some users to choose a higher price/higher quality option over a lower price/lower quality one. ${ }^{28}$

Williamson also discusses execution problems which are caused by uncertainty, for example, about technology, demand, supply and inflation. If the exclusive licensing conditions lock the bidder into a specific set of arrangements that retrospectively are found not to be appropriate for the buyer's purposes, there is a corresponding loss of efficiency.

\footnotetext{
${ }^{26}$ Users may have preferences that in an open market would be expressed in a menu of horizontally and vertically differentiated choices.

${ }^{27}$ As an example of non-price conditions, it is worth noting part of the criteria on which the Bunbury Port Authority decided to award the exclusive licence for the Port of Bunbury. This provided:

For qualitative services, tenders will be assessed on the basis of:

Relevant experience and corporation capacity (5\% weighting); Continuity of towage services (20\% weighting); Provision of services 24 hours per day 365 days per year (10\% weighting); To meet the requirement of continuity of towage services respondents are to provide the required services details and copies of agreements which commit the Licensee and its employees to the provision of services at all times.

${ }^{28}$ See Viscusi, W., J Vernon and J Harrington (1998) Economics of regulation and antitrust, $2^{\text {nd }}$ edition, MIT Press at pp. 421-422.
} 
Similarly, bidders may be unable to optimise their own responses to a changing environment.

The "execution problem" arises because market forces can no longer act as a corrective mechanism during the period of the exclusivity. As noted above, use of an exclusive license creates an entry barrier which prevents competitive pressure being applied to incumbents. This requires the regulator to carefully monitor the winning tenderer's conduct to ensure that the terms of the contract are properly enforced. Otherwise, outcomes could be worse than they would have been under open entry. Monitoring costs, and the cost of quality slippage hidden from the port authority, may not be negligible. Further, these costs are ongoing. ${ }^{29}$ It is estimated that the port authority may need to conduct formal operational audits every 6 to 12 months, as well as set up a formal complaints and a dispute resolution process. The total resource cost of monitoring a single harbour towage bid was recently estimated to be around $\$ 1$ million. ${ }^{30}$ In contrast, under open entry with a non-exclusive licence, market pressures play a substantial role in policing contract execution, including the delivery of quality outcomes.

\subsubsection{Losses in dynamic efficiency because of bunching of innovations and effects on bargaining}

An additional potential problem are the possible losses in dynamic efficiency caused by the way exclusive licences may lead to the "bunching" of innovations.

Under exclusive licences, firms have little incentive to implement costly innovations within the franchise period if the value of those innovations spans successive franchise periods and cannot be fully recouped in the event of exit. ${ }^{31}$ Even if the level of innovation under exclusive licensing reaches that of open entry, innovation may be too concentrated in the early stages of the exclusive license, reducing social welfare. In contrast, the incentives to innovate under open entry are continuous. As a result, the "locking out" effect of an exclusive licence can distort incentives to reduce costs, improve quality and introduce service innovations at least in the period over which the franchise is granted. This is a separate problem to the possible reductions in quality created by an inability to fully specify and monitor the franchisee's performance under existing technology, which was the subject of the previous section.

These dynamic efficiency considerations may be particularly significant in the case of harbour towage in Australia. This activity has traditionally been dominated by a strongly unionised workforce and by relatively inefficient work practices. This makes it important that towage firms be willing to undertake investments in increasing labour productivity,

\footnotetext{
${ }^{29}$ Charles River Associates (2002) "Exclusive licensing of harbour towage services in Australian ports: An analysis of the potential costs," pp. 22-23.

${ }^{30}$ The estimate includes the costs to the port authority, five bidders and their advisers in bidding and quality assurance and contract management costs. See ACIL Consulting (2002) "Exclusive licensing of port towage services".

${ }^{31}$ This argument is also made at p. 31 of Charles River Associates (2002) "Exclusive licensing of harbour towage services in Australian ports: An analysis of the potential costs":

"The standard of service required, the conditions under which the services will be performed and the specific KPIs [key performance indicators] that must be complied with under the exclusive licence contract impose a great degree of rigidity into an otherwise flexible market. This may have the effect of reducing the level of innovation as the incumbent's sole incentive is to achieve the designated KPIs at least cost to maximise its profit under the contract."
} 
including through the introduction of more efficient work practices. There is a risk here than an exclusive licence will grant trade unions additional power in contract negotiations.

Consider the incentives facing a towage provider tendering for and winning a five-year licence (the typical length of an exclusive licence is between five and seven years). On the one hand, the tenderer faces an enterprise bargaining agreement (EBA) of a maximum three-year duration; on the other hand, in order to win future bids, it must demonstrate its reliability throughout the life of the tendering process. This raises the prospect of union hold-up when the EBA expires midway through the exclusive licence period. Since port authorities have commonly imposed liquidated damages provisions for towage operators' service breaches, in embarking on labour reform, the towage provider must take two substantial expected costs into account:

- The costs of a strike, including liquidated damages, for breaching some reliable service term in the tender; and

- The costs of possibly losing the next tender round because of the unreliability of service exhibited during the strike.

Since new entrants also face similar difficulties, and hence must take these into account in bidding for any exclusive licence, the effect can be to make it more likely that firms will accede to union demands, raising the price of bids in each tender round.

That said, it is true that there are respects in which the exclusive license may increase the towage firm's incentive and ability to invest in enhancing labour productivity. For example, the fact of exclusivity means that the firm can appropriate for itself all of the gains from the productivity improvements, to the extent to which the contract does not require them to be passed on, for the period of the exclusivity. Additionally, if the attempt to improve work practices leads to industrial dispute, the firm will know that it will not lose market share to rivals during any disruption. Finally, the lack of alternative employment opportunities at the port may reduce employees' outside options, enhancing the towage operator's bargaining position.

The net impact of these factors is an empirical question. What is clear, however, is that significant improvements in labour productivity occurred in the period prior to the shift to exclusive contracts. Thus, Appendix 1 presents a case study of investments in work practices reform undertaken by Adsteam during a period of open competition in major Australian ports.

Essentially, Adsteam undertook substantial reform in labour reforms despite reservations from its own customers. Although Adsteam's customers agreed such reforms needed to be undertaken, and hence were encouraging of the reforms, they were reluctant to bear any short-term transition costs involved. Adsteam was confident that if it lost any customers because of short-term disruption, they could be won back immediately once the long lasting benefits were forthcoming. As Adsteam was operating in what it considered to be a relatively competitive market, it could credibly threaten its workforce that, in the absence of adequate reform, there was a prospect of job loss due to more efficient entry in the near future.

In effect, under open entry, an entrant might be able to arrange a more efficient set of conditions on workers willing to obtain new jobs. This would not only pressure the incumbent to attain similar improvements, but would mean a successful entrant (and its employees) must maintain its edge to prevent being similarly displaced. However, under the exclusive licence arrangement, the entrant and its potential employees know that any 
EBA will be due for renewal two or more years prior to the expiry of the exclusive licence. The risk of disruption at that point may compromise reforms that, from the point of view of securing an efficient, internationally competitive waterfront, need to be achieved. The social costs of threatening this reform process could loom large relative to any gains exclusive licensing could bring.

In summary, exclusive licensing may affect both the timing and extent of innovation. With respect to timing, the issues arise mainly because of the uncertainties as to whether investments in innovation made late in a contract period can be recouped. With respect to the extent of innovation, an especially significant concern in the Australian context relates to issues associated with improving work practices. These concerns are accentuated by disparities between the legally allowed duration of labour market contracts and exclusive licences.

\subsubsection{Bidding parity?}

The third problem discussed in Williamson's critique of franchise bidding is the possible lack of bidding parity fostered between the incumbent and the entrant at the end of the licensing period. When the life of sunk-cost investments exceeds the period of the franchise contract, an incumbent would tend to view the current cost of these investments as effectively zero. It may therefore outbid any potential entrant into the market. Williamson argues that if there is to be meaningful competition at the contract renewal stage, winners of the original competition should not be placed at a substantial advantage over non-winners. This requires that there be low sunk costs, in particular, if there are regulatory difficulties in monitoring contractual performance. Thus if the proponents of exclusive licensing justify their case in part by allegedly high sunk costs involved in entry, these very same high sunk costs would also weigh against the probability of exclusive licensing working well.

Furthermore, the absence of sunk costs, required for exclusive licensing to work over the long term, also negates the need for exclusive licensing in the first place. This is because the absence of sunk costs would enable effective competition in harbour towage.

A final possibility is that, if sunk costs are low and the costs of bidding for a monopoly franchise are high, entrants that would have entered under open competition may not consider it worth their while to bid at auction.

\section{Summary and conclusions}

It is reasonable to assume that at least some ports in Australia may only be able to support one operator, though one which faces strong exposure to competitive disciplines because of low barriers to entry. Nor is there any disagreement that, at least in the short term, exclusive licensing can encourage more entry and so increase the intensity of competition for the market. What is at issue is whether the expanded entry facilitated by exclusive licensing necessarily promotes longer-term efficiency and consumer welfare. This paper has attempted to demonstrate, using the case study of Australian harbour towage that the assumption that any increased entry promoted by exclusive licensing is a net gain is questionable when the incentives of the licensor are realistically considered.

In particular, port authorities as licensors may have an interest in increasing hidden fees and charges to towage providers and forcing reductions in the prices of towage services below levels that would recover sunk costs investments in innovation. Exclusive 
licensing, which expands entry and increases competition, increases the means available to achieve these objectives. This would reduce incentives for towage providers to make future investments in innovation and would therefore reduce long run efficiency.

The paper has argued that even if there is no such port authority conflict of interest, there are other costs inherent to exclusive licensing which cannot be easily avoided - for example, costs associated with contractual design and enforcement, bidding parity problems and distortions in the timing of investments and labour and exclusive licence timing issues.

Taking these costs into account, the question of whether there are any real and sustainable benefits to consumers that can come from exclusive licensing is still open. Indeed, in the case of harbour towage, any short-term price reductions, to the extent that they arise, could increase longer-term costs (and ultimately prices) in harbour towage. The current system of open entry has brought long-term investments (such as reforming work relations) which significantly lowered industry costs.

The arguments presented in this paper suggest two directions for future research. Firstly, the theory of how the port authority's incentive structure impacts on its licensing policies could be expanded and applied to analyse exclusive licensing under different assumptions about the objective function of the authority. This can lead to some empirically testable hypotheses about how ports with different governance structures relate to different licensing arrangements. Secondly, the arguments in this paper suggest that contract design in the Australian case of exclusive licensing for harbour towage can cause an inefficiently low level of investment. With a comprehensive collection of industry data, it may be possible to perform an econometric regression relating some measure of investment levels in ports to a variety of factors including dummy variables representing the presence or absence of exclusive licensing.

\section{$7 \quad$ References}

ACIL Consulting (2002) "Exclusive Licensing of Port Towage Services," http://www.pc.gov.au/inquiry/harbourtowage/

Armstrong, M. S. Cowan and J. Vickers (1994) Regulatory Reform: Economic Analysis and British Experience. The MIT Press: Cambridge, Mass., and London, England.

E. Chadwick (1859) "Results of Different Principles of Legislation in Europe: Of Competition for the Field as Compared with Competition within the Field of Service," Journal of the Royal Statistical Society, 22: 381.

Charles River Associates (2002) "Exclusive Licensing of Harbour Towage Services in Australian Ports: An Analysis of the Potential Costs". http://www.pc.gov.au/inquiry/harbourtowage/

Demsetz, H. (1971) "On the Regulation of Industry: A Reply," Journal of Political Economy, 79: 357.

Gans, J. and S. King (2003) "Contestability, complementary inputs and contracting: The case of harbour towage," Australian Economic Review, 36: 415-27. 
Goldberg, V. P. (1976) "Regulation and Administered Contracts," The Bell Journal of Economics, 7: 426-48.

Klein, B. (1996) "Why Hold-Ups Occur: The Self-Enforcing Range of Contractual Relationships," Economic Inquiry, 34: 444-63.

Littlechild, S. (2002) "Competitive Bidding for a Long-Term Electricity Distribution Contract," Review of Network Economics, 1: 1-38.

Posner, R. A. (1972) "The Appropriate Scope of Regulation in the Cable Television Industry," The Bell Journal of Economics and Management Science, 3: 98-129.

Ramseyer, J.M. and Y. Miwa (2000) "Rethinking Relationship-Specific Investments: Subcontracting in the Japanese Automobile Industry," Harvard Law and Economics Discussion Paper No. 282.

Schmalensee, R. (1979) The Control of Natural Monopolies. D.C. Heath \&Co.: Lexington.

Stigler G. J. (1968) The Organisation of Industry. University of Chicago Press, Chicago.

Viscusi, W., J Vernon and J Harrington (1998) Economics of regulation and antitrust, 2nd edition, MIT Press.

Williamson, O E (1976) "Franchise Bidding for Natural Monopolies - in General and with Respect to CATV," The Bell Journal of Economics, 7: 73-104.

Williamson, O. (1985) The Economic Institutions of Capitalism. Free Press: New York. 